\title{
Managing soil nitrate with cover crops and buffer strips in Sicilian vineyards
}

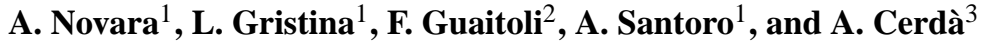 \\ ${ }^{1}$ Dipartimento di Scienze Agrarie e Forestali, Viale delle Scienze, 90128 Palermo, Italy \\ ${ }^{2}$ Assessorato Risorse Agricole e Alimentari, Regione Siciliana, Palermo, Italy \\ ${ }^{3}$ SEDER Soil Erosion and Degradation Research Group, Departament de Geografia, Universitat de València, \\ Blasco Ibañez 28, 46010, Valencia, Spain
}

Correspondence to: A. Novara (agata.novara@unipa.it)

Received: 7 March 2013 - Published in Solid Earth Discuss.: 3 April 2013

Revised: 5 June 2013 - Accepted: 14 June 2013 - Published: 9 August 2013

\begin{abstract}
When soil nitrate levels are low, plants suffer nitrogen $(\mathrm{N})$ deficiency but when the levels are excessive, soil nitrates can pollute surface and subsurface waters. Strategies to reduce the nitrate pollution are necessary to reach a sustainable use of resources such as soil, water and plant. Buffer strips and cover crops can contribute to the management of soil nitrates, but little is known of their effectiveness in semiarid vineyards plantations. The research was carried out in the south coast of Sicily (Italy) to evaluate nitrate trends in a vineyard managed both conventionally and using two different cover crops (Triticum durum and Vicia sativa cover crop). A $10 \mathrm{~m}$-wide buffer strip was seeded with Lolium perenne at the bottom of the vineyard. Soil nitrate was measured monthly and nitrate movement was monitored by application of a ${ }^{15} \mathrm{~N}$ tracer to a narrow strip between the bottom of vineyard and the buffer and non-buffer strips. Lolium perenne biomass yield in the buffer strips and its isotopic nitrogen content were monitored. Vicia sativa cover crop management contributed with an excess of nitrogen, and the soil management determined the nitrogen content at the buffer areas. A $6 \mathrm{~m}$ buffer strip reduced the nitrate by $42 \%$ with and by $46 \%$ with a $9 \mathrm{~m}$ buffer strip. Thanks to catch crops, farmers can manage the $\mathrm{N}$ content and its distribution into the soil over the year, can reduced fertilizer wastage and reduce $\mathrm{N}$ pollution of surface and groundwater.
\end{abstract}

\section{Introduction}

Mediterranean agriculture soils are being subjected to intense land degradation (Cerdà et al., 2010) due to the intensification of the agriculture practices. This intensification increases the misuse of herbicides and pesticides, leading to soil biological degradation (Garcia Orenes et al., 2009) and soil erosion (Cerda et al.,2009a). The impact of new agriculture systems are that they are highly mechanized and chemical farming and irrigation (see Cerdà et al., 2009b) contributed to environmental problems such as soil and water pollution (Semaan et al., 2007). The last concept of agriculture intensification, applied by new generation of farmers involves new strategies to avoid those environmental problems through human labour increase. An example is the use of catch crops to maintain the soil fertility and preserve soil erosion (Novara et al., 2011), as well as the use of geotextiles to reduce the soil losses (Giménez Morera et al., 2011).

Over the last decades in the semiarid Mediterranean environment, high external inputs of nitrate and irrigation in intensively managed agricultural systems reduced surface and subsurface water quality (Butturini et al., 2003; Lassaletta et al., 2009). In particular, vineyard soils are conventionally managed and frequently tilled, which reduces the vegetation cover and increases the proportion of bared soil. This induces a high rate of organic matter mineralization and nitrate leaching (Cerejeira et al., 2000). There are other crops in the Mediterranean that are affected by similar problems such as the olive plantations (Gomez et al., 2009) under rainfed production but also on drip irrigated land. Cerdà et al. (2009b) 
found an increase of soil erosion rates and soil degradation. Presently, vineyards are moving fast to drip irrigation and chemical fertilization and little research has been conducted to determine the environmental impacts of the land management change.

To reduce the loss of nitrate in soils and the pollution of ground- and surface water, European directives have favored Good Agricultural Practices, such as the reduction of mineral nitrogen fertilization or the establishment of vegetated buffer strips (Council Directive 91/676/EEC, 1991). Buffer strips are vegetated zones adjacent to agroforestry or crop fields that intercept and "treat" the water draining the cropland (Dillahaet al., 1988; Dosskey, 2001). Buffer strips reduce the movement of sediment, nutrients, and pesticides from agricultural lands into the ecosystem (Borinet al., 2010; Borinet al., 2002; Patty et al., 1997; Popov et al., 2005; Rankins et al., 2001; Schmitt et al., 1999; Tingle et al., 1998). Buffer effectiveness depends on buffer characteristics such as surface hydraulic properties, vegetation species, soil type, slope morphology, and buffer width (Balestrini et al., 2011; Bharati et al., 2002; Dunn et al., 2011; Schmitt et al., 1999). Buffer strip efficacy is also affected by the agricultural system (land management and crop) and the management practices used in the buffered area (Bedard-Haughn et al., 2005).

Although cover-cropping reduces nitrate leaching (Ritter et al., 1998; Thomsen, 2005; Tonitto et al., 2006), decreases soil erosion, (Novara et al., 2011; Quinton and Catt, 2004) and improves soil aggregation, water infiltration, and waterholding capacity (Kuoet al., 1997; Villamil et al., 2006), leguminous cover crops can result in excess nitrate content in soil due to his capacity to fix nitrogen.

For vineyards, little information is available on how leguminous versus cereal cover crops affect the distribution and retention of soil nitrate during the year. This information is needed to avoid an excess or deficit in soil nitrate according to grapevine needs. Knowledge on how to avoid excess or deficit of soil nitrate could be useful local policymakers to match different needs between the "Nitrate directive" which limits nitrate use to reduce water pollution and "Agroecological measures" that favor the use of leguminous cover crop to improve farm sustainability.

The goals of this study are to: (i) evaluate the spatial and temporal variation in soil nitrate content in a vineyard; (ii) compare the effects of alternative and conventional soil management on soil nitrate content; (iii) compare the effect of leguminous vs. cereal cover crops on soil nitrate dynamics over time; and (iv) evaluate the ability of buffer strips of different widths to retain nitrate.

\section{Materials and methods}

The separate and combined effect of cover crops and buffer strips on nitrate dynamics in vineyard was evaluated in Agrigento province $\left(37^{\circ} 35^{\prime} 12^{\prime \prime} \mathrm{N}, 13^{\circ} 01^{\prime} 41^{\prime \prime} \mathrm{E}\right.$; $85 \mathrm{~m}$ a.s.1), Sicily

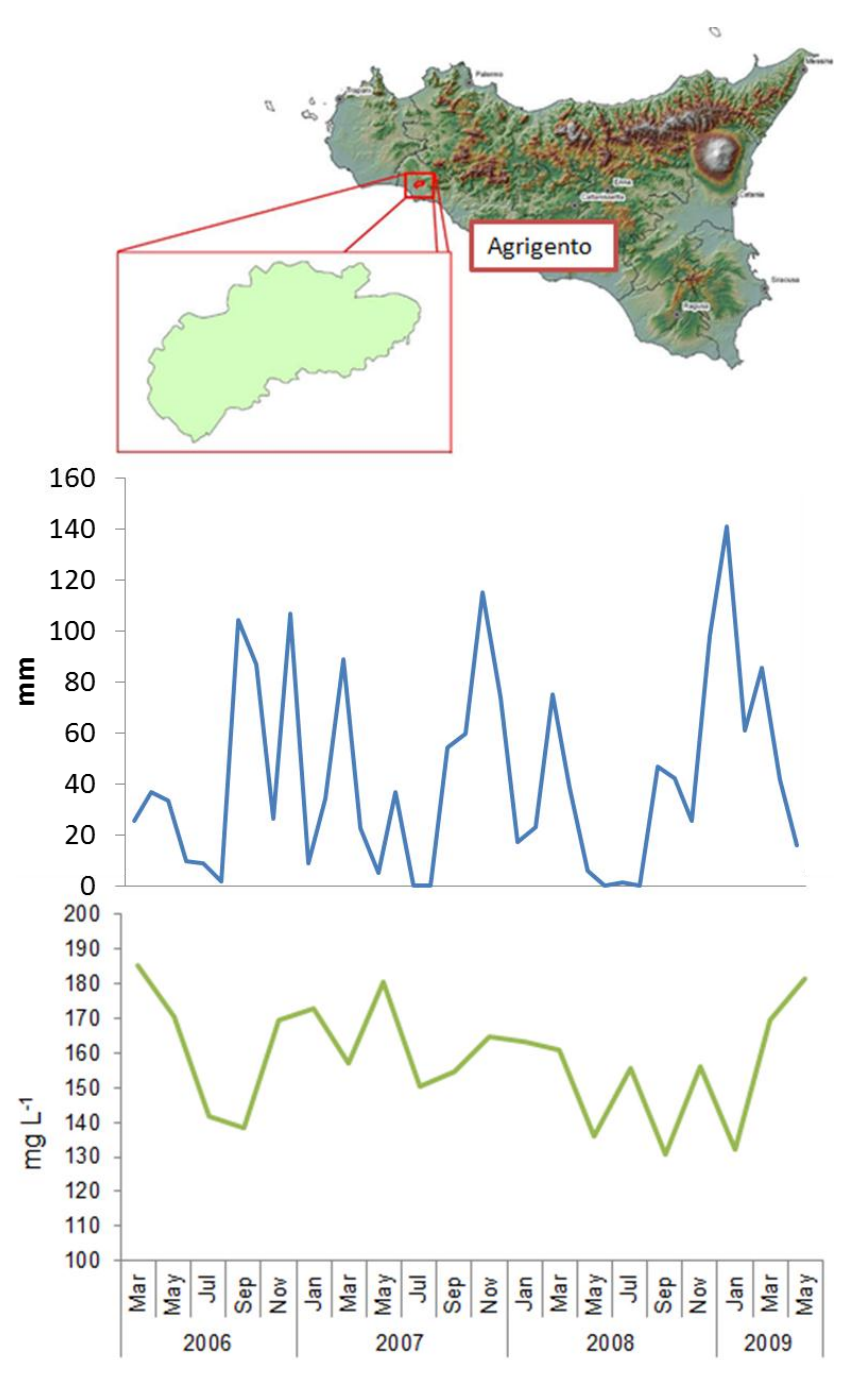

Fig. 1. Study area (top), monthly rainfall (red bars) and average groundwater nitrate concentration from 2006 to 2008 (green line).

(Italy) (Fig. 1a). Soils around the study area (Fig. 1b) are at high risk of nitrate contamination according to a "map of nitrate vulnerable zone in Sicily" (scale 1:250 000) developed by the Sicilian regional government (Regione Sicilia, Decreto D.D.G. n. 121, 2005). Farmers in this area apply conventional soil management (3-4 ploughings per year, $0.15 \mathrm{~m}$ deep, to bury weeds and aerate the topsoil), which increases the levels of soil nitrate in the groundwater. The nitrate content of the groundwater exceeds $50 \mathrm{mg} \mathrm{L}^{-1}$, which is considered polluted (Nitrates Directive, 1991). During the period of observation (March 2006 to May 2009), the groundwater nitrate concentration always exceeded $130 \mathrm{mg} \mathrm{L}^{-1}$, with a maximum of $190 \mathrm{mg} \mathrm{L}^{-1}$ in summer (Fig. 1b).

The study was conducted in a vineyard that lies on a $260^{\circ} \mathrm{N}$ slope with $7 \%$ angle slope. The area has a typical Mediterranean climate with dry, hot summers and moist winters. Precipitation data from Sciacca $\left(41^{\circ} 62^{\prime} \mathrm{N}, 32^{\circ} 69^{\prime} \mathrm{E}\right.$; $90 \mathrm{~m}$ a.s.1.) weather station were used. The mean annual 


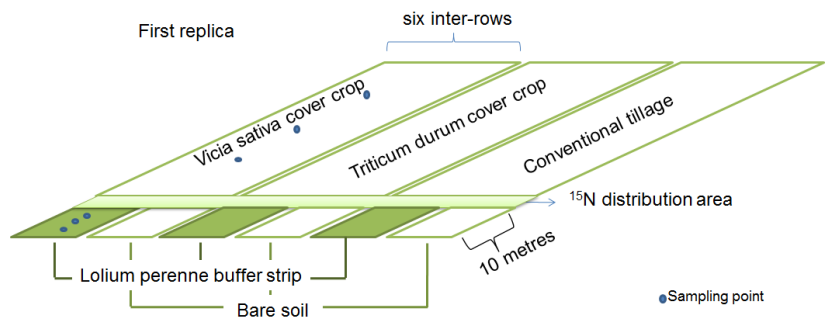

Fig. 2. Experimental design.

precipitation is $516 \mathrm{~mm}$. Most rain falls in autumn and winter, and rainfall is highest in October (monthly mean rainfall of $81 \mathrm{~mm}$ ) and lowest in July (monthly mean rainfall of $2 \mathrm{~mm}$ ) (Fig. 1c). On average, $3 \%$ of the mean annual rainfall occurs during summer (June, July, and August) while $42 \%$ occurs during winter (November, December, and January). The mean annual temperature is $18^{\circ} \mathrm{C}$; the hottest months are July and August (monthly means of about $25^{\circ} \mathrm{C}$ ), and the coldest months are January and February (monthly means of $11^{\circ} \mathrm{C}$ ). Soil in the experimental field is classified as a HapliEutricVertisol according to the Word Reference Base for Soil Resources (WRB, 2006). The top soil $(0-20 \mathrm{~cm}$ ) is composed mainly by $57.1 \%$ of clay, $34 \%$ of silt and $8.9 \%$ of sand, measured based on the pipette method (Day, 1965). The soil had a pH of 8 , a CEC of 30.9 meq $100 \mathrm{~g}^{-1}$ and $187 \mathrm{~g} \mathrm{~kg}^{-1}$ of total carbonate.

The research was carried out in a non-irrigated 10-year old vineyard of the Merlot variety. Vine plant density was 4500 plant $\mathrm{ha}^{-1}$, rows were $80 \mathrm{~m}$ long with $2.2 \mathrm{~m}$ between rows. The experiment included three treatments in which the soil between the vine rows (along slope) was managed with Triticum durum L. cover crop (T), with a Vicia sativa L. cover crop (V), and by conventional tillage (C) in a randomized block design. The first block or replicate of the experiment is represented in Fig. 2. Within each block, each treatment was applied to six adjacent inter-rows, giving 18 adjacent inter-row per block. Cover crops were seeded in October 2006 and in October 2007 with specialized sod-seeding equipment, and cover crop biomass was turned into the soil by rotary tillage in April 2007 and April 2008. For treatment $\mathrm{C}$, the soil was ploughed 3-4 times per year $(0.15 \mathrm{~m}$ deep, starting after the first rain in September) depending on weed control needs and to aerate the topsoil. The vineyard was not fertilized.

At the bottom of the vineyard and perpendicular to the direction of slope in the field, a strip of soil that was $10 \mathrm{~m}$ wide and $80 \mathrm{~m}$ long was divided into buffer strips and non-buffer strips so that each treatment plot had one buffer strip and one non-buffer strip at its downslope base (see Fig. 2). The buffer strips were seeded with Lolium perenne ( $40 \mathrm{~kg}$ of seed per $\mathrm{ha}^{-1}$ ) in October 2005, one year before the beginning of experiment. The non-buffer strips were managed by conventional tillage. The experiment had a total of three blocks.
Soil samples were collected once per month from January 2007 to June 2008 from the central inter-row of each treatment. Soil samples (three subsamples for each treatment) were taken at $0-20 \mathrm{~cm}$ depth along the slope at intervals of $20 \mathrm{~m}$ in the vineyard plot (average of three soil samples for each sampling position) and at intervals of $3 \mathrm{~m}$ in the buffer zone (average of three soil samples for each sampling position); the samples within each plot were kept separate so that nitrate content along the slope could be quantified. The positions with respect to slope for both the treatment and strip plots are referred to as upper, middle, and lower. Aboveground biomass of Lolium perenne in the buffer strips was collected in April, May, and June of 2007 and 2008 for determination of yield and ${ }^{15} \mathrm{~N}$ content. Vicia sativa and T. $d u$ rum biomass were sampled in April of both years (before the cover crops were incorporated into the soil) by removing the aboveground biomass in three $1 \mathrm{~m}^{2}$ areas per replicate; dry weight and $\mathrm{N}$ content were determined.

The dynamics of nitrate in the soil and vegetation of the buffer strip were monitored with nitrogen isotopes, which are stable and nonradioactive (Powlson and Barraclough, 1993). We used an ${ }^{15} \mathrm{~N}$-enriched tracer, and the natural abundance background levels of ${ }^{15} \mathrm{~N}$ was measured before the application. The tracer was sprayed onto the surface of a $1 \mathrm{~m}$ strip of soil that separated the buffer and non-buffer strips from the rows treated with T, V, and C (Fig. 2) in the first week of February for both years (2007 and 2008). The tracer was an aqueous solution of ammonium sulphate $\left(1.57 \%{ }^{15} \mathrm{~N}\right.$ atom $)$ sprayed at $80 \mathrm{~kg} \mathrm{ha}^{-1}$.

To monitor water and sediment yield, a $1 \mathrm{~m}$-wide Gerlach (Gerlach, 1967; Morgan, 1977) with a 40 L deposit was installed at the bottom buffer and non-buffer site. During the study period no water runoff was recorded at the bottom of the plot in both treatments. The cover of T. durum and Vicia sativa and the tillage management enhanced the infiltration and, as a consequence, overland flow was negligible.

The $\mathrm{NO}_{3}-\mathrm{N}$ content of the soil samples was determined by aqueous extraction with a Dionex D120 ion chromatograph. Soil and plant samples were subjected to isotopic analysis with an EA-IRMS (elemental analyser-isotopic ratio mass spectrometer). An automatic sampler was used, and the samples were combusted in the presence of oxygen at $1050{ }^{\circ} \mathrm{C}$.

Isotopic levels for the soils and plants are reported as atom $\%{ }^{15} \mathrm{~N}$ excess, which refers to the amount of ${ }^{15} \mathrm{~N}$ present relative to the average naturally occurring background ${ }^{15} \mathrm{~N}$ levels occurring in the biomass and the soil under the specific experimental conditions. Background levels are based on pre-application samples. Where possible, atom $\%{ }^{15} \mathrm{~N} \mathrm{ex}-$ cess amounts were extrapolated to get the total amount of ${ }^{15} \mathrm{~N}$ in a given pool by weight and thus to determine a ${ }^{15} \mathrm{~N}$ budget (Bedard-Haughnand van Kessel, 2004).

The international standard for $\mathrm{N}$ is atmospheric nitrogen (Mariotti, 1983 and 1984), for which the ${ }^{15} \mathrm{~N} /{ }^{14} \mathrm{~N}$ ratio is 0.003676 . The international reference materials IAEA$\mathrm{N} 1\left(\delta^{15} \mathrm{~N}=0.03 \% \circ\right)$, IAEA-N2 $\left(\delta^{15} \mathrm{~N}=20.1 \%\right)$, IAEA-N3 
Table 1. Results of the ANOVA test for $\mathrm{NO}_{3}-\mathrm{N}$ in vineyard and buffer zone.

\begin{tabular}{lcrrr}
\hline & & Vineyard & Buffer & No buffer \\
\hline & DF & & & \\
Soil Management (M) & 2 & $<0.0001$ & $<0.0001$ & $<0.0001$ \\
Slope position (S) & 2 & 0.0307 & 0.0302 & 0.0405 \\
$\mathrm{M} \times \mathrm{S}$ & 4 & 0.9221 & 0.5857 & 0.7687 \\
Time (T) & 17 & $<0.0001$ & $<0.0001$ & $<0.0001$ \\
$\mathrm{M} \times \mathrm{T}$ & 34 & $<0.0001$ & 0.2378 & 0.2601 \\
\hline
\end{tabular}

$\left(\delta^{15} \mathrm{~N}=4.5 \%\right.$ ) were used for calibration and normalization following the study of Bohlke et al. (2003). Analytical precision is about $0.2 \%$. A split plot design with three replications was used in which management was defined as the main plot, and elevations (position on slope, i.e., upper, middle, and lower) were subplots. After testing normal distribution of data (Bartlett test of homogeneity of variances for $p>0.05$ ), statistical analysis was carried out separately for the managed area (treatments $\mathrm{T}, \mathrm{V}$, or $\mathrm{C}$ ) and the buffer strip/non-buffer strip area on the quantity of $15 \mathrm{~N}$ detected in buffer strips and non-buffer strips below the treatment plot and nitrate. Nitrate content was also compared using repeated measure ANOVA carried out according to the used experimental design (SAS, 2002)

\section{Results and discussion}

\subsection{Soil nitrate content in the vineyard}

The nitrate content was $12.4 \%$ greater in treatment V vs. C but only $1.71 \%$ greater in treatment $\mathrm{T}$ vs. C. These significant differences $(p \leq 0.0001)$ (Table 1$)$ can be explained by the ability of the legume, Vicia sativa, to fix $\mathrm{N}$ and by the high $\mathrm{N}$ content of the legume tissue. Before the cover crops were incorporated into the soil, the aboveground dry biomass was $11 \pm 1.2 \mathrm{Mg} \mathrm{ha}^{-1}$ (with $2.8 \% \mathrm{~N}$ content) for treatment $\mathrm{V}$ and $8.33 \pm 2.1 \mathrm{Mg} \mathrm{ha}^{-1}$ (with $1.3 \% \mathrm{~N}$ content) for treatment $\mathrm{T}$.

Our results are in agreement with previous studies, which observed that cover crops increase soil $\mathrm{N}$ content and soil organic matter (SOM) content (Jackson et al, 2004; Sainju et al., 2000, Ramos et al., 2010). In the experimental site we hypothesized a SOM increase after moving catch crops into the soil. The potential to immobilize and retain soil $\mathrm{N}$ increases with SOM content (Barretta and Burke, 2000). Continuous tillage under conventional management, in contrast, causes bare soil (weed free) and an increased $\mathrm{N}$ loss due to leaching, short-term bursts of mineralization of organic $\mathrm{N}$ substrates, and nitrous dioxide efflux (Grandy and Robertson, 2006). Consequently, soil nitrate content was lower in the conventionally managed plots than in the plots with catch crops.
Soil nitrate content changed during the year, apparently because of precipitation, mineralization, uptake by vines and cover crops. Cover crops have direct and indirect effects on soil fertility and vine nutrition. Incorporation of leguminous catch crops directly adds organic nitrogen to the soil (Nakhone and Tabatabai, 2008). After mineralization, which begins within weeks after incorporation, this nitrogen is available for vine uptake (Rupp, 1996). In contrast, non-leguminous cover crops often result in the depletion of the vineyard nitrogen pool (Celette et al., 2009). The interactions between cover crop, soil fertility, and vine growth are complex and dynamic. Measuring and predicting changes in soil nutrient status can be far more difficult in cover-cropped vineyards than in vineyards managed with chemical fertilizers alone, as the farmer controls the source of nitrogen.

Soil nitrate values were lower in spring and high in late summer or autumn (Fig. 3). The values ranged from 1.45 to $26.56 \mathrm{mg} \mathrm{L}^{-1}$ under conventional tillage, from 1.71 to $28.14 \mathrm{mg} \mathrm{L}^{-1}$ under the Vicia sativa cover crop, and from 1.87 to $19.71 \mathrm{mg} \mathrm{L}^{-1}$ under the T. durum cover crop.

The strong decrease of nitrate from winter to early spring can be attributed to leaching in response to precipitation under conventional tillage (Davidson, 1992) and to plant uptake of $\mathrm{N}$ in the cover crop treatments (Steenwerth and Belina, 2008). In summer, the high increase in nitrate under the Vicia sativa cover crop and with conventional tillage might be explained by rapid mineralization of organic matter. The peak in soil nitrate was lower with the Triticum durum treatment than with the other two treatments, probably because of the relatively high carbon-to-nitrogen ratio and lignin content of Triticum durum, which would reduce its rate of mineralization when it was incorporated into the soil.

Considering the average of nitrate content measured in the first and second year, insignificant differences were found for the conventionally managed plots and for Vicia sativa plots. On the contrary, the values were higher in the second year in the Triticum durum plots. The latter difference is consistent with previous reports that $\mathrm{N}$ can be immobilized following the planting of some cereal cover crops (Fageria et al., 2005).

In all treatments, soil nitrate content increased down the slope. The soil nitrate content in the middle and lower tram of the slope increased by 48 and $112 \%$ in the V. sativa plots, by 47 and $123 \%$ in the Triticum durum plots, and by 37 and $94 \%$ in the conventionally managed plots, respectively. This data demonstrate the leaching of nitrates by the surface wash and subsurface wash, and confirm that the bottom buffer strips of the slope can be a good strategy to avoid pollution with nitrates. The results showed that nitrates are leached by surface and subsurface wash. It also confirms that the buffer strips are a good strategy to mitigate nitrate soil pollution.

\subsection{Soil nitrate in the buffer and non-buffer strips}

Soil nitrate content was higher in the non-buffer strips (without Lolium perenne) than in the buffer strips (with Lolium 

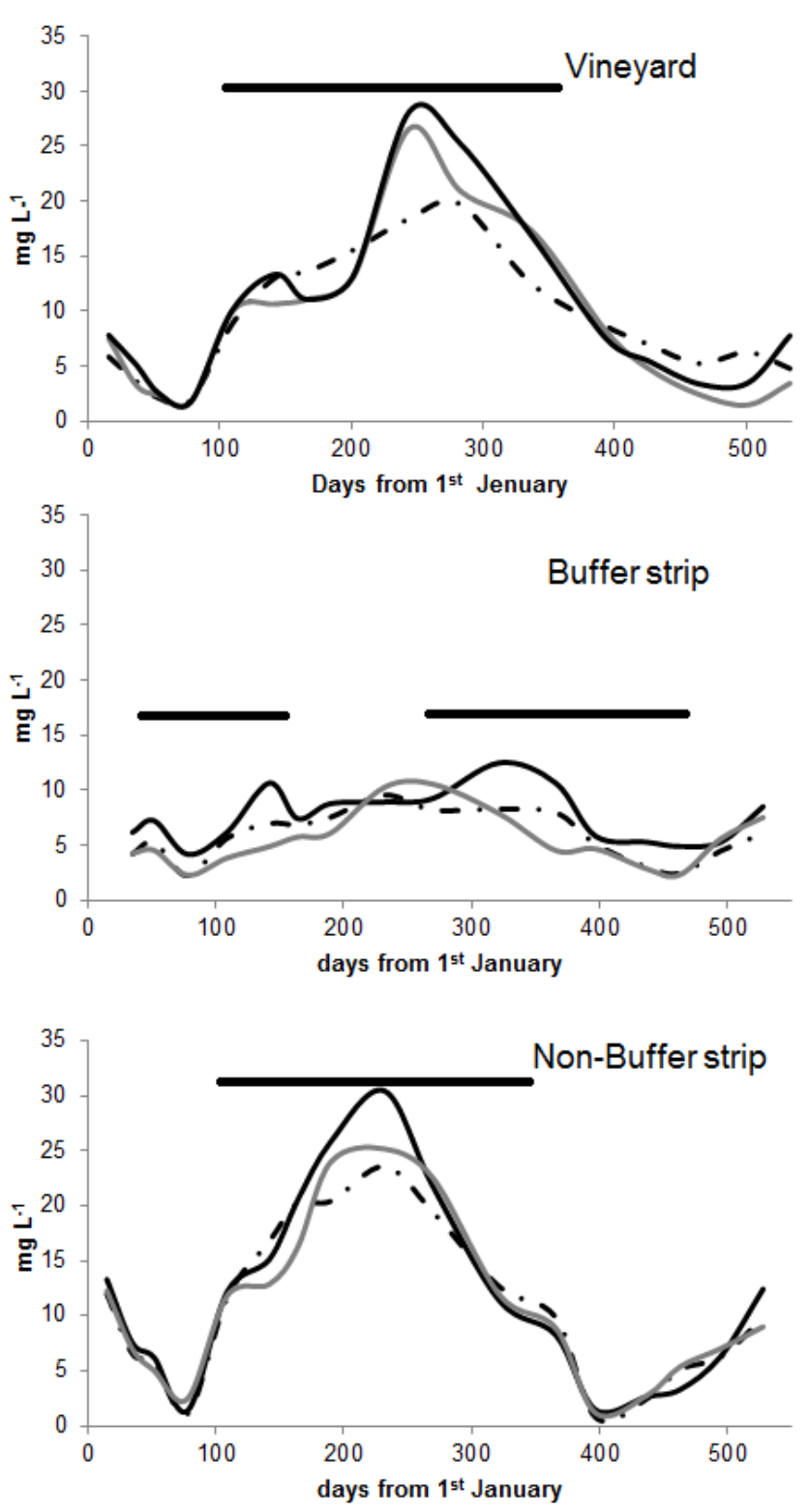

Fig. 3. Soil nitrate content in vineyard plots (a) (average of upper, middle and lower position), buffer strips (b) and non-buffer strips (c) below the Vicia sativa cover crop (black line), the Triticum durum cover crop (grey line), and conventional tillage (broken line). Horizontal lines represent statistical difference $(p<0.005)$ according to ANOVA repeated measure statistical analysis test.

perenne) and was higher in late summer and autumn than in spring (Fig. 3b, c). Soil nitrate content ranged from 2.26 to $12.5 \mathrm{mg} \mathrm{L}^{-1}$ in buffer strips and from 1.5 to $30.5 \mathrm{mg} \mathrm{L}^{-1}$ in the non-buffer strip (Fig. 3b, c). This result is consistent with the idea that a buffer strip can capture excess nitrate throughout the whole year and retain nitrate in soil during the rainiest periods, thereby reduce leaching (Leeds-Harrison et al., 1999). Note that a large quantity of nitrate that accumulated during summer (a period with low precipitation) in the non-

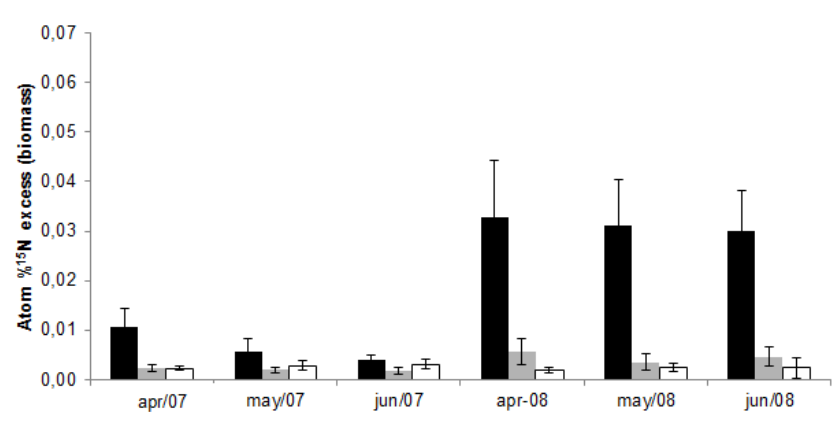

Fig. 4. Atom $\%{ }^{15} \mathrm{~N}$ excess in Lolium perennein the buffer strips vs. the time. Black, grey, and white bars represent 3, 6, and $9 \mathrm{~m}$ distances ( 3 samples for each distance), respectively, from the ${ }^{15} \mathrm{~N}$ application zone. The vertical lines represent standard deviation.

buffer strips was completely lost by the end of winter in both years of observation due to runoff and leaching.

Soil nitrate content was $25 \%$ and $35 \%$ higher in the middle and lower slope positions than in the upper slope position. In the buffer strips, however, nitrate content was only $12 \%$ and $14 \%$ higher in the middle and lower positions than in the upper position. These results agree with other research concerning $\mathrm{N}$ removal as a function of buffer width (BedardHaughnet al., 2005; Dillaha et al., 1989). Statistical analysis showed differences only between upper and middle position and between the upper and lowest position of the strips (Table 1).

Soil nitrate content in buffer (Table 1) and non-buffer strips was significantly affected by vineyard soil management (treatments $\mathrm{V}, \mathrm{T}$, and $\mathrm{C}$ ). In the non-buffer strip, differences were significant only during summer, when soil nitrate content was highest with treatment $\mathrm{V}$, lowest with treatment $\mathrm{C}$, and intermediate with treatment $\mathrm{T}$. In the buffer strips, soil nitrate over all sampling times tended to be highest with treatment $\mathrm{C}\left(8.1 \mathrm{mg} \mathrm{L}^{-1}\right)$, followed by treatment $\mathrm{T}$ $\left(6.1 \mathrm{mg} \mathrm{L}^{-1}\right)$, and treatment $\mathrm{V}\left(5.7 \mathrm{mg} \mathrm{L}^{-1}\right)$. These differences are consistent with the effects of vineyard soil management on losses of nitrate by subsurface water flow.

\section{3 $\quad 15 \mathrm{~N}$ tracer in biomass}

The mean dry biomass of Lolium perenne in the buffer strips was unaffected by soil management treatments and averaged $4.14 \pm 0.85 \mathrm{Mg} \mathrm{ha}^{-1}$. The ${ }^{15} \mathrm{~N}$ uptake by Lolium perenne tended to decrease with distance from the narrow strip where ${ }^{15} \mathrm{~N}$ was applied, and was significantly greater at $3 \mathrm{~m}$ downslope than at $6 \mathrm{~m}$ or $9 \mathrm{~m}$ downslope but did not differ between $6 \mathrm{~m}$ and $9 \mathrm{~m}$ downslope (Fig. 4). The Lolium perenne located $6 \mathrm{~m}$ and $9 \mathrm{~m}$ from the application zone contained 72 and $76 \%$ less isotopic excess, respectively, than the Lolium perenne located only $3 \mathrm{~m}$ from the application zone. Values of isotopic excess ranged from $0.01 \pm 0.038 \%$ o to $0.0018 \pm 0.0007 \%$ after the first application and from $0.0329 \pm 0.011 \%$ o to 
$0.0019 \pm 0.0006 \%$ after the second application of ${ }^{15} \mathrm{~N}$ tracer (Fig. 4).

The ${ }^{15} \mathrm{~N}$ excess decreased over time after each application (Fig. 4), indicating dilution of the ${ }^{15} \mathrm{~N}$ signature caused by uptake of non-enriched N (Bedard-Haughn et al., 2004).

\section{4 $\quad 15 \mathrm{~N}$ tracer in soil}

${ }^{15} \mathrm{~N}$ isotopic excess in the soil was higher in the non-buffer strips than in the buffer strips (Fig. 5). In the buffer strip soil, atom $\%{ }^{15} \mathrm{~N}$ excess ranged from $0.0028 \pm 0.0011 \%$ o to $0.0042 \pm 0.0013 \%$ after the first application, and from $0.0026 \pm 0.0002 \%$ o to $0.0074 \pm 0.0017 \%$ ofter the second application of ${ }^{15} \mathrm{~N}$ tracer (Fig. 5). Averaged over time and location in the strip, values were $15 \%$ higher in the non-buffer strips than in the buffer strips.

Relative to the content of ${ }^{15} \mathrm{~N}$ isotopic excess in the buffer strip soil at $3 \mathrm{~m}$ from the application site, the content was $42 \%$ and $46 \%$ lower at $6 \mathrm{~m}$ and $9 \mathrm{~m}$, respectively, from the application zone (Fig. 5). In contrast, the content of ${ }^{15} \mathrm{~N}$ isotopic excess in the non-buffer strip increased with distance down the slope from the application site. Relative to the content of ${ }^{15} \mathrm{~N}$ isotopic excess in the non-buffer strip soil at $3 \mathrm{~m}$ from the application site, the content in the buffer strip was 4 and $91 \%$ higher at $6 \mathrm{~m}$ and $9 \mathrm{~m}$, respectively, from the application zone (Fig. 5).

\subsection{Implications}

Vineyard plantations in the Mediterranean region can be managed with a cover crop and a vegetative buffer strip in order to reduce nitrates excessive concentration in soils and water. Relative to conventional tillage, a cover crop provides a better distribution of soil nitrogen in time and space with respect to grapevine growth requirements, while the vegetative buffer strip captures the excess nitrate and thereby reduces pollution of surface and groundwater by nitrate. Soil nitrate content was lower with conventional tillage $\left(108 \mathrm{~kg} \mathrm{ha}^{-1}\right)$ than with the cover crops $\left(110 \mathrm{~kg} \mathrm{ha}^{-1}\right.$ for $T$. durum and $122 \mathrm{~kg} \mathrm{ha}^{-1}$ for Vicia sativa), with a peak during the hottest period of the year (August). This temporal distribution of soil nitrate does not fit to grapevine nutrients needs and as a consequence there is a nutrient deficit during the growing period and an excess in summer until the first rain in autumn, when nitrate are leached and eroded by the surface wash. Soil under conventional tillage is unable to retain nitrate, and then, $\mathrm{N}$ fertilization is applied. This will increase the $\mathrm{N}$ wash.

In the Mediterranean area, soil management with a cover crop in the winter reduces the soil, water and nitrates losses. This research demonstrate that cover or catch crops contribute to the nitrogen fixation (Vicia sativa). Because of biological fixation of $\mathrm{N}$, leguminous cover crops provide a net $\mathrm{N}$ input to vineyards (King and Berry 2005; Drinkwater et al., 1998).

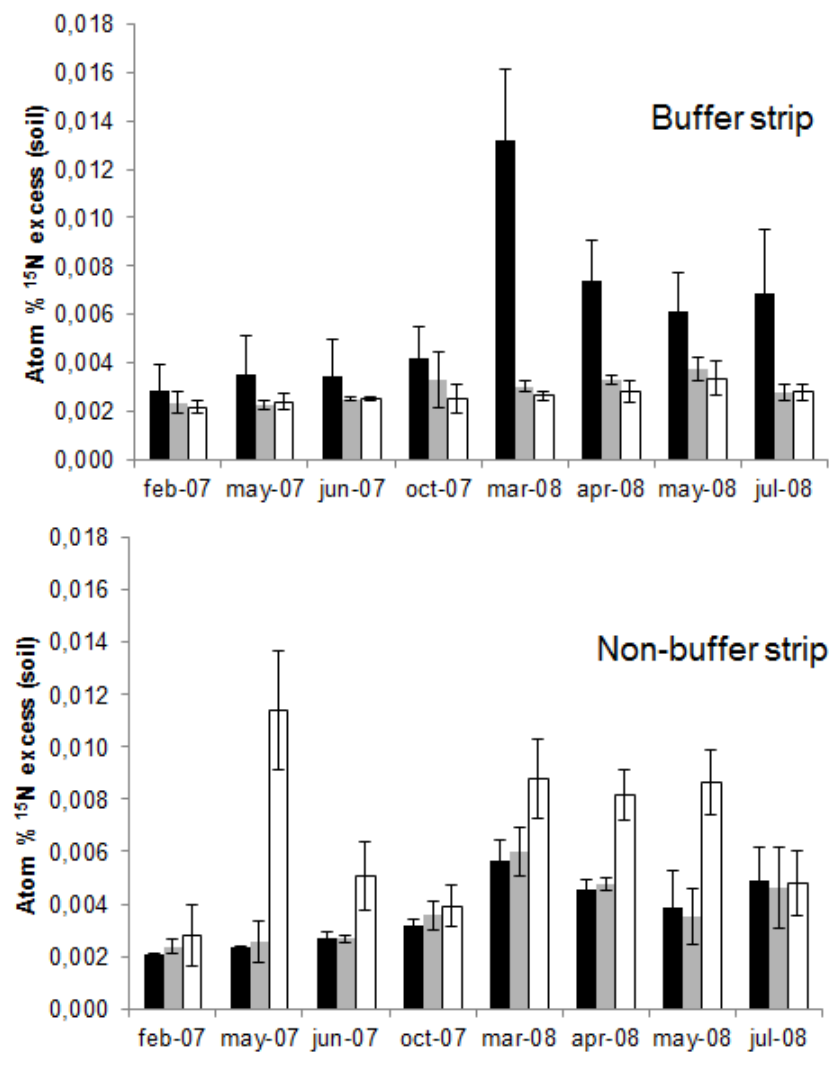

Fig. 5. Atom $\%{ }^{15} \mathrm{~N}$ excess in soil over the time in the buffer strips and non-buffer strips. Black, grey, and white bars represent 3, 6, and $9 \mathrm{~m}$ distances ( 3 samples for each distance), respectively, from the ${ }^{15} \mathrm{~N}$ application zone. The vertical lines represent standard deviation.

Cover crops are a valuable alternative to chemical fertilizers in vineyards, it is important to evaluate not only the amount of $\mathrm{N}$ added to the system but also the $\mathrm{N}$ availability during the year. In our case, the Vicia sativa cover crop experienced a high mineralization rate in summer, when grapevines cannot utilize nitrate. Because it contributes less nitrogen and has a higher $\mathrm{C}: \mathrm{N}$ ratio, the Triticum durum cover crop may result in less pollution and greater retention of $\mathrm{N}$ than either the Vicia sativa cover crop or the conventional soil management system.

The high nitrate content at the edge of vineyard is likely to move into water supplies unless captured by a buffer strip. Buffer effectiveness in reducing nitrate loss was demonstrated by the use of a ${ }^{15} \mathrm{~N}$ tracer. Most of the applied ${ }^{15} \mathrm{~N}$ tracer was found in the biomass of Lolium perenne in the first $3 \mathrm{~m}$ of the buffer strip, indicating that the ${ }^{15} \mathrm{~N}$ tracer in soil decreased down the slope of the buffer strips. Although nitrate decrease varied with buffer width, we considered a $6 \mathrm{~m}$ buffer strip sufficient to control nitrate pollution in vineyards, like the most of Sicilian vineyards, with a slope of about $7 \%$. 


\section{Conclusions}

Cover crops in vineyard inter-rows under Mediterranean climatic conditions reduce water runoff and act as catch crops regulating nitrate availability during the year. Thanks to catch crops, farmers can manage the $\mathrm{N}$ content and its distribution into the soil over the year. In this way, vineyard managers can reduce fertilizer wastage and reduce $\mathrm{N}$ pollution of surface and groundwater. The main contribution of this research is that nitrate losses can be managed in vineyards successfully by the use of appropriate soil conservation practices and by installation of buffer strips.

Acknowledgements. We thank Assessorato Regionale Risorse Agricole e Alimentari Dipartimento I nterventi Infrastrutturali per Agricoltura Servizio VI Sistema I nformativo Territoriale Regione Siciliana for financial support.

Edited by: F. Terribile

\section{References}

Balestrini, R., Arese, C., Del Conte, C. A., Lotti, A., and Salrno, F.: Nitrogen removal in subsurface water by narrow buffer strips in the intensive farming landscape of the Po River 20 watershed, Italy, Ecol. Eng., 6, 148-157, 2011.

Barrett, J. E. and Burke, I. C.: Potential nitrogen immobilization in grassland soils across a soil organic matter gradient, Soil Biol. Biochem., 32, 1707-1716, 2000.

Bedard-Haughn, A., Tate, K. W., and van Kessel, C.: Using Nitrogen-15 to Quantify Vegetative Buffer Effectiveness for Sequestering Nitrogen in Runoff, J. Environ. Qual., 33, 2252-2262, 2004.

Bedard-Haughn, A., Tate, K.W., and van Kessel, C.: Quantifying the Impact of Regular Cutting on Vegetative Buffer Efficacy for Nitrogen-15 Sequestration, J. Environ. Qual., 34, 1651-1664, doi:10.2134/jeq2005.0033, 2005.

Bharati, L., Lee, K. H., Isenhart, T. M., and Schultz, R. C.: Soil water infiltration under crops, pasture, and established riparian buffer in Midwestern USA, Agroforest. Syst., 56, 249-257, 2002.

Bohlke, J. K., Mroczkoski, S. J., and Coplen, T. B.: Oxygen isotopes in nitrate: new reference materials for ${ }^{18} \mathrm{O}:{ }^{17} \mathrm{O}:{ }^{16} \mathrm{O}$ measurements and observations on nitrate-water equilibration, Rapid Commun. Mass Sp., 17, 1835-1846, 2003.

Borin, M. and Bigon, E.: Abatement of $\mathrm{NO}_{3}-\mathrm{N}$ concentration in agricultural waters by narrow buffer strips, Environ. Pollut., 117, 165-168, 2002.

Borin, M., Passoni, M., Thiene, M., and Tempesta, T.: Multiple functions of buffer strips in farming areas, Eur. J. Agronomy, 32, 103-111, 2010.

Butturini, A., Bernal, S., Hellin, C., Nin, E., Rivero, L., Sabater, S., and Sabater, F.: Influences of the stream groundwater hydrology on nitrateconcentration in unsaturated riparian area bounded by anintermittent Mediterranean stream, Water Resour. Res., 39, 1110, doi:10.1029/2001wr001260, 2003.
Cerdà, A., Flanagan, D. C., le Bissonnais, Y., and Boardman, J.: Soil erosion and agriculture, Soil Tillage Res., 106, 107-108, doi:10.1016/j.still.2009.10.006, 2009a.

Cerdà, A., Gimènez-Morera, A., and Bodì, M. B.: Soil and water losses from new citrus orchards growing on sloped soils in the western Mediterranean Basin, Earth Surf. Proc. Land., 34, 18221830, doi:10.1002/esp.1889, 2009b.

Cerdà, A., Lavee, H., Romero-Dìaz, A., Hooke, J., and Montanarella, L.: Soil erosionand degradation in mediterranean type ecosystems, Land Degrad. Dev., 21, 71-74, doi:10.1002/ldr.968, 2010.

Celette, F., Findeling, A., and Gary, C.: Competition for nitrogen in an unfertilized intercropping system: The case of an association of grapevine and grass cover in a Mediterranean climate, Eur. J. Agronomy, 30, 41-51, 2009.

Cerejeira, M. J., Silva, E., Batista, S., Trancoso, A., Centeno, M. S. L., and Silva Fernandes, A.: Simazine, metribuzine and nitrates in ground water of agricultural areas of Portugal, Toxicol. Environ. Chem., 75, 245-253, 2000.

Council Directive 91/676/EEC: available at: http://ec.europa.eu/ environment/water/water-nitrates/directiv.html, 1991.

Davidson, E. A.: Sources of nitric oxide and nitrous oxide following wetting of dry soil, Soil Sci. Soc. Am. J., 56, 95-102, 1992.

Day, P. R.: Particle fractionation and particle-size analysis, in: Methods of Soil Analysis, Part 1, edited by: Black, C. A., American Society of Agronomy, Inc., Madison, WI, 545-567, 1965.

Dillaha, T. A., Sherrard, J. H., Lee, D., Mostaghimi, S., and Shanholtz, V. O.: Evaluation of vegetative filter strips as a best management practice for feed lots, J. Water Pollut. Control Fed., 60, 1231-1238, 1988.

Dillaha, T. A., Reneau, R. B., Mostaghimi, S., and Lee, D.: Vegetative filter strips for agricultural non point source pollution control, Trans. ASAE, 32, 513-519, 1989.

Dosskey, M. G.: Toward quantifying water pollution in response to installing buffers on crop land, Environ. Manage, 28, 577-598, 2001.

Drinkwater, L., Wagoner, P., and Sarrantonio, M.: Legume based cropping systems have reduced carbon and nitrogen losses, Nature, 396, 262-265, 1998.

Dunn, A. M., Julien, G., Ernst, W. R., Cook, A., Doe, K. G., and Jackman, P. M.: Evaluation of buffer zone effectiveness in mitigating the risks associated with agricultural runoff in Prince Edward Island, Sci. Total Environ., 409, 868-882, 2011.

Fageria, N. K., Baligar, V. C., and Bailey, B. A.: Role of cover crops in improving soil and row crop productivity, Commun. Soil Sci. Plann., 36, 2733-2757, doi:10.1080/00103620500303939, 2005.

García-Orenes, F., Cerdà, A., Mataix-Solera, J., Guerrero, C., Bodí, M. B., Arcenegui, V., Zornoza, R., and Sempere, J. G.: Effects of agricultural management on surface soil properties and soilwater losses in eastern Spain, Soil Till. Res., 106, 117-123, doi:10.1016/j.still.2009.06.002, 2009.

Gerlach, T.: Hillslope troughs for measuring sediment movement, Rev. Geom. Dyn., 4, 173-175, 1967.

Giménez Morera, A., Ruiz Sinoga, J. D., and Cerdà, A.: The impact of cotton geotextiles on soil and water losses in Mediterranean rainfed agricultural land, Land Degrad. Develop., 21, 210-217, doi:10.1002/ldr.971, 2010.

Grandy, A. S. and Robertson, G. P.: Initial cultivation of a temperate-region soil immediately accelerates aggregate 
turnover and $\mathrm{CO}_{2}$ and $\mathrm{N}_{2} \mathrm{O}$ fluxes, Glob. Change Biol., 12, 1507-1520, 2006.

Jackson, L. E., Ramirez, I., Yokota, R., Fennimore, S. A., Koike, S. T., Henderson, D. M., Chaney, W. E., Calderon, F. J., and Klonsky, K.: On-farm assessment of organic matter and tillage management on vegetable yield, soil, weeds, pests, and economics in California, Agr. Ecosyst. Environ., 103, 443-463, 2004.

King, A. P. and Berry, A. M.: Vineyard $\delta^{15} \mathrm{~N}$, nitrogen and water status in perennial clover and bunch grass cover crop systems of California's central valley, Agr. Ecosyst. Environ., 109, 262-272, 2005.

Kuo, S., Sainju, U. M., and Jellum, E. J.: Winter cover crop effects on soil organic carbon and carbohydrate in soil, Soil Sci. Soc. Am. J., 61, 145-152, 1997.

Lassaletta, L., García-Gómez, H., Gimeno, B. S., and Rovira, J. V.: Agriculture-induced increase in nitrate concentrations in stream waters of a large Mediterranean catchment over $25 \mathrm{yr}$ (1981-2005), Sci. Total Environ., 407, 6034-6043, doi10.1016/j.scitotenv.2009.08.002, 2009.

Leeds-Harrison, P. B., Quinton, J. N., Walker, M. J., Sanders, C. L., and Harrod, T.: Grassed buffer strips for the control of nitrate leaching to surface waters in headwater catchments, Ecol. Eng., 3, 299-313, 1999.

Mariotti, A.: Atmospheric nitrogen is a reliable standard for natural ${ }^{15} \mathrm{~N}$ abundance measurements, Nature, 303, 685-687, 1983.

Mariotti, A.: Natural ${ }^{15} \mathrm{~N}$ abundance measurements and atmospheric nitrogen standard calibration, Nature, 311, 251-252, 1984.

Morgan, R. P. C.: Soil Erosion and Conservation, 3 Edn., Blackwell, Oxford, 2005

Nakhone, L. N. and Tabatabai, M. A.: Nitrogen mineralization of leguminous crops in soils, J. Plant Nutr. Soil Sc., 171, 231-241, 2008.

Novara, A., Gristina, L., Saladino, S. S., Santoro, A., and Cerdà, A.: Soil erosion assessment on tillage and alternative soil managements in a Sicilian vineyard, Soil Tillage Res., 117, 140-147, 2011.

Patty, L., Réal, B., and Gril, J.: The use of grassed buffer strips to remove pesticides, nitrate and soluble phosphorus compounds from runoff water, Pestic. Sci., 49, 243-251, 1997.

Popov, V. H., Cornish, P. S., and Sun, H.: Vegetative biofilters: the relative importance of infiltration and adsorption in reducing loads of water-soluble herbicides in agricultural runoff, Agr. Ecosyst. Environ., 114, 351-359, 2005.

Powlson, D. S. and Barraclough, D.: Mineralization and assimilation in soil-plant systems, in: Nitrogen Isotope Techniques, edited by: Blackburn, T. H., Academic Press, New York, 209239, 1993.

Quinton, J. N. and Catt, J. A.: The effects of minimal tillage and contour cultivation on surface runoff, soil loss and crop yield in the long-term Woburn Erosion Reference Experiment on sandy soil at Woburn, England, Soil Use Manage., 20, 343-349, doi10.1111/j.1475-2743.2004.tb00379.x, 2004.
Ramos, M. E., Benítez, E., García, P. A., and Robles, A. R.: Cover crops under different managements vs. frequent tillage in almond orchards in semiarid conditions: effects on soil quality, Appl. Soil Ecol., 44, 6-14, 2010.

Rankins, J. A., Shaw, D. R., and Boyette, M.: Perennial grass filter strips for reducing herbicide losses in runoff, Weed Sci., 49, 647651, 2011.

Regione Sicilia: Decreto D. D. G. n. 121, available at: http://www.regione.sicilia.it/Agricolturaeforeste/Assessorato/ CartaNitratiHome.htm, 2005.

Ritter, W. F., Scarborough, R. W., and Chirnside, A. E. M.: Winter cover crops as a best management practice for reducing nitrogen leaching, J. Contam. Hydrol., 34, 1-15, 1998.

Rupp, D.: Green cover management to optimize the nitrogen supply of grapevines, in: Proc. Workshop Strategies to Optimize Wine Grape Quality, Acta Hort., 427, 57-62, 1996.

Sainju, U. M., Singh, B. P., and Whitehead, W. F.: Long-term effects of tillage, cover crops, and nitrogen fertilization on organic carbon and nitrogen concentrations in sandy loam soils in Georgia, USA, Soil Tillage Res., 63, 167-179, 2002.

SAS Institute: The SAS System for Microsoft Windows, Release 8.2., SAS Institute, Cary, NC, 2002.

Schmitt, T. J., Dosskey, M. G., and Hoagland, K. D.: Filter strip performance and processes for different vegetation, widths, and contaminants, J. Environ. Qual., 28, 1479-1489, 1999.

Semaan, J., Flichman, G., Scardigno, A., and Steduto, P.: Analysis of nitrate pollution control policies in the irrigated agriculture of Apulia Region (Southern Italy): A bio-economic modelling approach, Agr. Syst., 92, 357-367, doi:10.1016/j.agsy.2006.10.003, 2007.

Steenwerth, K. L. and Belina, K. M.: Cover crops and cultivation: impacts on soil $\mathrm{N}$ dynamics, nitrous oxide efflux, and microbiological function in a Mediterranean vineyard agroecosystem, Appl. Soil Ecol., 40, 370-380, 2008.

Thomsen, I. K.: Nitrate leaching during under spring barley is influences by the presence of a ryegrass catch crop: results from a lysimeter experiment, Agr. Ecosyst. Environ., 11, 21-29, 2005.

Tingle, C. H., Shaw, D. R., Boyette, M., and Murphy, G. P.: Metolachlor and metribuzin losses in runoff as affected by width of vegetative filter strips, Weed Sci., 46, 475-479, 1998.

Tonitto, C., David, M. B., and Drinkwater, L. E.: Replacing bare fallows with cover crops in fertilizer-intensive cropping systems: a meta-analysis of crop yield and $\mathrm{N}$ dynamics, Agr. Ecosyst. Environ., 112, 58-72, 2006.

Villamil, M. B., Bollero, G. A., Darmody, R. G., Simmons, F. W., and Bullock, D. G.: No till corn/soybean systems including winter cover crops: effects on soil properties, Soil Sci. Soc. Am. J., 70, 1936-1944, 2006.

World Reference Base for Soil Resources: A framework for international classification, correlation and communication, Rome, Italy, 128 pp., 2006. 